JURNAL

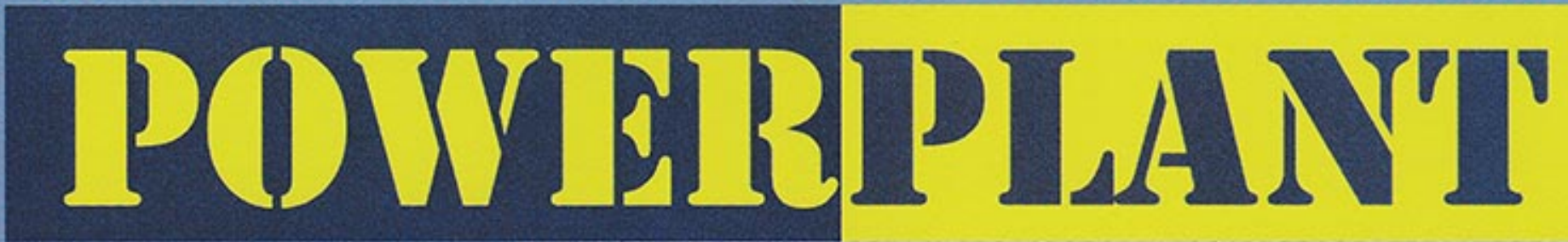

Roswati Nurhasanah

Jasmid Edy

Eza Brian Pradana

\section{Arief Suardi}

Vendy Antono

Al Asyi

Arisma Chairul Syarif Iman Kartolaksono R Jalu Eko Harjono

Nofirman

Yusuf Rasyid

Win Alfalah

Eko Sulistyo

Rahmat Ikhsan

Utami Wahyuningsih

Halim Rusjdi

Eko Sulistiyo

Sahlan

Jumiati

Intan Ratna Sari Yanti

Sri Yayi
Perancangan Boiler Dengan Memanfaatkan Sampah

Kering Untuk Bahan Bakar PLTU Mini 3 kW STT-PLN

Analisis Perbandingan Penggunaan Big Oil Gun dan Tiny Oil Gun terhadap Kosumsi Bahan Bakar Pada Saat Strat Up Unit di PLTU Banten Lontar

Uji Prestasi dan Emisi Diesel Berbahan Bakar Minyak Nabati Murni untuk Pembangkitan Daya di Daerah Terpencil

Pengukuran Suhu Pembakaran di Dalam Boiler : Pirometer Akuistik VS Pirometer Infared

Pengaruh Pemeliharaan Overhoul Turbo Charger

Terhadap Kinerja Mesin Unit VII PLTD Ampenan

Penanggulangan Korosi Pada Pipa Gas Dengan Metode Catodic Protection (Anoda Karbon) PT PGN Solution Area Cengkareng

Analisis Strategi Teknologi PLTS Fotovoltik di Indonesia Terhadap Nilai Eqivalensi dan Pemanfatan Per Wilayah

Pengembangan Model Pembelajaran Berbasis Tutorial Bagi Mahasiswa Teknik Mesin STT PLN

\begin{tabular}{|c|c|c|c|c|c|c|}
\hline 111 & & $\mathrm{SE}$ & OLAH & INGGI TEY & PLN (STT-PLN) & \\
\hline$\||\|||| \mid$ & JURNAL POWERPLANT & VOL. 5 & NO. 1 & HAL. 1.63 & NOVEMBER 2017 & ISSN No :2356-1513 \\
\hline
\end{tabular}




\title{
PERANCANGAN BOILER DENGAN MEMANFAATKAN SAMPAH KERING UNTUK BAHAN BAKAR PLTU MINI 3 kW STT-PLN
}

\author{
Roswati Nurhasanah \\ Jasmid Edy \\ Eza Brian Pradana \\ Jurusan Teknik Mesin, Sekolah Tinggi Teknik - PLN \\ Email : roswati@sttpln.ac.id
}

\begin{abstract}
Boiler is a heat exchanger that serves to evaporate boiler feed water to produce dry steam to drive the turbines in order to produce electricity. The fuels used in this study are dry wastes such as paper, plastic, and wood. The process of designing this boiler is carried out so that the use of diesel to generate steam on energy conversion practicum/experiment in STT-PLN is no longer needed. Instead, they can use dry waste as fuel to produce steam which later will drive the turbines. The residue of burning waste process in the form of ashes is approximately 0.053\% of the weight or volume of dry waste before burnt. The calculation conducted on this works is to determine the design of evaporator and economizer pipe. The calculation is also adjusted to the generated steam needed in order to spin the turbines. The pressure produced from this boiler design should be 2.9 bar and for the amount of steam was $21 \mathrm{~kg} /$ hour. As a result, the calculation of evaporator surface area is $8,83 \mathrm{~m}^{2}$, result simulation HTRI $8.95 \mathrm{~m}^{2}$ with 88 pipes and $1500 \mathrm{~mm}$ for each pipe, while the heated surface area for economizer is $0,46 \mathrm{~m}^{2}$ result simulation HTRI 0,45 $\mathrm{m}^{2}$ with 18 pipes and $400 \mathrm{~mm}$ long for each pipe.
\end{abstract}

Keywords: Boiler, evaporator, economizer, dry wastes, fuels

\section{PENDAHULUAN}

Permasalahan sampah merupakan masalah kompleks yang dihadapi setiap kota besar, permasalahan ini timbul ketika jumlah sampah meningkat namun tidak diiringi dengan peningkatan tindakan dan sarana pengelolahan sampah. Salah satu jenis sampah yang memerlukan perhatian khusus adalah sampah anorganik (kertas, plastik, styrofoam, dll) karena sifatnya yang sulit diurai tanah sehingga sampah ini akan bertahan lama menjadi sampah. Adapun salah satu upaya penanganan jenis sampah kering dengan pembuatan Tungku SIDAUS untuk mereduksi volume sampah kering dengan cara pembakaran sudah berhasil dilakukan dengan rata-rata kemampuan tungku bakar sampah dilihat dari kecepatanya adalah 15,91 kg/jam (Jasmid, 2016), akan tetapi hasil pembakaran tersebut hanya berupa abu, sedangkan jika ditinjau dari nilai kalor, maka sampah memiliki LHV dengan nilai antara 675,26 sampai 12195,08 kcal/kg.

Disisi lain, boiler yang merupakan salah satu komponen PLTU Mini untuk menguapkan air pengisi sehingga menghasilkan superheated steam yang akan digunakan untuk mengexpansi turbin agar mampu menghasilkan energi listrik kapasitas 3kW yang ada di Laboratorium Konversi Energi STT-PLN, saat ini bahan bakar yang digunakan masih menggunakan solar murni dengan LHV $10710.9 \mathrm{kCal} / \mathrm{kg}$. sehingga dibutuhkan energi alternatif yang dapat menggantikan sumber daya tidak terbarukan seperti bahan bakar fosil. Energi ini dapat digantikan oleh energi yang terkandung di dalam sampah, dikenal dengan konsep waste to energy (Dian, 2010).

Salah satu upaya dalam penanganan sampah yang ada di STT -PLN adalah memanfaatkan sampah kering sebagai bahan bakar pada sebuah boiler mini. Sehingga hasil pembakaran sampah kering dapat dimanfaatkan sebagai bahan bakar alternatif pengganti solar di PLTU Mini khususnya untuk kegiatan praktikum Konversi Energi.

\section{KAJIAN LITERATUR}

PLTU adalah jenis pembangkit listrik tenaga termal yang banyak digunakan, karena 
efisiensinya tinggi sehingga menghasilkan energi listrik yang ekonomis. PLTU merupakan mesin konversi energi yang mengubah energi kimia dalam bahan bakar menjadi energi listrik. Bahan bakar pada PLTU pada umumnya menggunakan batubara, minyak, dan gas. Akan tetapi pada pembangkit listrik tenaga sampah bahan bakar dari pembangkit tersebut berupa sampah. Sampah dibakar menghasilkan menghasilkan gas panas yang nantinya gas panas tersebut mengubah air yang masuk kedalam boiler menjadi uap jenuh yang nantinya diteruskan ke superheater untuk dijadikan uap panas lanjut sehingga dapat memutarkan turbin. Daya yang dihasilkan pada pembangkit listrik tenaga sampah ini bervariasi antara $500 \mathrm{~kW}$ sampai 10 MW Pembangkit Listrik Tenaga Uap.

Boiler merupakan mesin kalor (thermal engineering) yang mentransfer energi-energi kimia atau energi otomis menjadi kerja (usaha) (Muin, 1988). Boiler atau ketel uap adalah suatu alat berbentuk bejana tertutup yang digunakan untuk menghasilkan uap. Uap diperoleh dengan memanaskan bejana yang berisi air dengan bahan bakar (Yohana dan Askhabulyamin, 2009). Boiler mengubah energi-energi kimia menjadi bentuk energi yang lain untuk menghasilkan kerja. Boiler dirancang untuk melakukan atau memindahkan kalor dari suatu sumber pembakaran, yang biasanya berupa pembakaran bahan bakar. Boiler berfungsi sebagai pesawat konversi energi yang mengkonversikan energi kimia (potensial) dari bahan bakar menjadi energi panas. Boiler terdiri dari dua komponen utama, yaitu:

1. Dapur sebagai alat untuk mengubah energi kimia menjadi energi panas.

2. Alat penguap (evaporator) yang mengubah energi pembakaran (energi panas) menjadi energi potensial uap (energi panas).

Secara garis besar terdapat dua macam teknologi pengolahan sampah yaitu teknologi pembakaran (incineration) dan teknologi fermentasi metana. (Safrizal, 2014). Untuk menentukan performa sampah kering dalam penggunaannya sebagai bahan bakar perlu dilakukan analisis mengenai sifat-sifatnya berdasarkan unsur-unsur pembentuknya dalam basis persen massa Heating valuenya (nilai kalor). Ada dua jenis analisis berdasarkan unsur-unsur pembentuknya yang biasa dipakai yaitu proximate dan ultimate. Dalam analisis proximate, tentukan persen massa dari fixed carbon, volatile matter (unsur yang mudah menguap), moisture (kandungan air) dan ash (abu). Ketiga unsur pertama tadi ditentukan berdasarkan ANSI (American National Standards Institution) / ASTM D 3172 sedangkan unsur yang terakhir ditentukan berdasarkan ANSI / ASTM D 2492. Analisis ultimate menganalisis sifat dari suatu sampah kering berdasarkan persentasi massa dari unsur $\neg$ unsur kimia yang membentuknya, yaitu persentasi massa dari karbon (C), hidrogen (H2) oksigen (O2), nitrogen (N2), sulfur (S) dan abu (Ash). Analisis tersebut ditentukan berdasarkan standar ASTM D 3176.

RDF adalah hasil proses pemisahan limbah padat antara fraksi sampah mudah terbakar dan tidak mudah terbakar seperti metal dan kaca (Cheremisiniff, 2003). Besarnya daya kWh yang dibangkitkan erat kaitannya dengan nilai kalor. Dimana nilai kalor sangat diperngaruhi oleh kadar air dan hidrogen sampah. Hasil pengurangan nilai kalor ini, LHV, biasanya digunakan sebagai bahan pertimbangan dalam pemilihan teknologi pengolahan dan aplikasi WTE. Nilai kalor juga dipengaruhi oleh kadar volatil dan abu. Semakin tinggi kadar volatil yang terbakar, nilai kalor semakin tinggi. Besarnya nilai kalor dari berbagai sampah dapat dilihat pada table 1 dibawah ini. 
Tabel 1 Nilai Kalor dari berbagai sampah (Dian, 2010)

\begin{tabular}{|c|c|c|c|c|c|c|c|}
\hline \multirow{3}{*}{ No } & \multirow{3}{*}{ Sampel } & \multicolumn{6}{|c|}{ Nilai Kalor (kcal/kg) } \\
\hline & & \multirow{2}{*}{\begin{tabular}{c|c|} 
Bom \\
Kalorimeter
\end{tabular}} & \multirow{2}{*}{ LHV } & \multicolumn{2}{|c|}{ Proximate Analysis } & \multicolumn{2}{|c|}{ Dulong } \\
\hline & & & & 1 & 2 & $3^{*}$ & $3 * *$ \\
\hline & Kertas & & & & & & \\
\hline 1 & HVS & 3024,24 & 2884,84 & 4234,29 & 1143,01 & & 3591,18 \\
\hline 2 & Karton & 3602,18 & 3359,17 & 4118,58 & 1154,28 & 6648,26 & \\
\hline 3 & Koran & 3845,53 & 3618,95 & 4238,47 & 1306,64 & 4205,97 & \\
\hline 4 & Majalah & 2598,95 & 2476,51 & 3646,23 & 992,02 & 2712,36 & \\
\hline 5 & Kertas Nasi & 4246,92 & 3920,67 & 4167,29 & 1288,89 & & 3591,18 \\
\hline \multirow[t]{2}{*}{6} & Kardus & 4487,07 & 4093,09 & 4257,12 & 1284,39 & 3571,67 & \\
\hline & Plastik & & & & & & \\
\hline 7 & PET Bottle (no.1) & 5450,85 & 5252,42 & 4445,83 & 1382,24 & 11680,56 & \\
\hline 8 & HDPE Lembaran (no.2) & 11207,00 & 11169,58 & 4444,73 & 1386,33 & & 6307,50 \\
\hline 9 & PVC lembaran (no.3) & 5187,91 & 5138,23 & 4332,82 & 1360,11 & 5448,78 & \\
\hline 10 & LDPE (no.4) & 12318,40 & 12195,08 & 4505,66 & 1356,34 & & 6307,50 \\
\hline 11 & PP Cup (no.5) & 11912,80 & 11903,06 & 4426,95 & 1380,54 & & 6307,50 \\
\hline \multirow[t]{2}{*}{12} & PS (no.6) & 11285,50 & 11269,80 & 4273,86 & 1379,38 & 9645,22 & \\
\hline & Sampah Makanan\&Pasar & & & & & & \\
\hline 13 & Makanan tercampur & 5162,21 & 1437,86 & 3727,54 & 737,10 & 4466,11 & \\
\hline 14 & Daun Pembungkus & 4638,37 & 975,59 & 4069,59 & 573,85 & & 4154,72 \\
\hline 15 & Batok\&gambut kelapa & 4684,11 & 3407,90 & 4446,86 & 1291,42 & & 3915,63 \\
\hline 16 & Sayur & 4568,29 & 689,85 & 4205,94 & 248,60 & & 4466,11 \\
\hline 17 & Ikan & 5837,12 & 1567,48 & 3497,23 & 581,39 & & 4466,11 \\
\hline 18 & Lemak & 9891,62 & 5065,61 & 4442,10 & 1213,95 & 9155,28 & \\
\hline 19 & Daging & 7154,78 & 2597,33 & 4359,15 & 1034,45 & & \\
\hline 20 & Tulang & 4464,42 & 1570,90 & 3169,97 & 638,29 & & 6951,46 \\
\hline \multirow[t]{2}{*}{21} & Buah & 5064,86 & 392,54 & 4337,90 & $-828,00$ & 4347,01 & \\
\hline & Sampah Kebun & & & & & & \\
\hline 22 & Daun & 3998,02 & 1632,60 & 3644,07 & 958,76 & & 4154,72 \\
\hline 23 & Rumput & 4153,51 & 906,08 & 7365,52 & 567,68 & & 4154,72 \\
\hline \multirow[t]{2}{*}{24} & Cabang pohon/ranting & 4715,66 & 1997,45 & 4211,09 & 1096,14 & & 3915,63 \\
\hline & Tekstil \& Karet & & & & & & \\
\hline 25 & Handuk & 4435,10 & 4239,45 & 4301,44 & 1348,27 & & 4357,78 \\
\hline 26 & Jeans & 4271,05 & 4010,65 & 4393,74 & 1372,21 & & 4357,78 \\
\hline 27 & Kaos & 4836,68 & 4664,32 & 4413,66 & 1365,93 & & 4357,78 \\
\hline \multirow[t]{2}{*}{28} & Karet & 5202,15 & 5106,45 & 4218,60 & 939,96 & 8598,61 & \\
\hline & Kompos & & & & & & \\
\hline 29 & Mentah & 2125,75 & 675,26 & 2402,29 & 420,93 & & 4137,50 \\
\hline 30 & 1/2 Matang & 2091,90 & 979,05 & 2291,37 & 484,83 & & 4137,50 \\
\hline 31 & Matang & 1669,73 & 936,04 & 1854,94 & 415,31 & & 4137,50 \\
\hline 32 & Residu & 2211,65 & 980,02 & 3007,37 & 680,21 & & 4137,50 \\
\hline
\end{tabular}

* data Tchobanoglous

** asumsi dari data Tchobanoglous

Tabel 2. Perbandingan Jenis bahan baku plastik dan temperature nyala api

\begin{tabular}{|c|l|c|l|c|}
\hline No & $\begin{array}{c}\text { Jenis Bahan } \\
\text { Baku }\end{array}$ & $\begin{array}{c}\text { Massa bahan } \\
\text { baku }\end{array}$ & \multicolumn{1}{|c|}{ Waktu Penyulingan } & Temperatur nyala api \\
\hline 1 & Kantong kresek & 500 gram & 15 menit 30 detik & $350{ }^{\circ} \mathrm{C}$ \\
\hline 2 & Botol oli & 500 gram & 25 menit 15 detik & $365^{\circ} \mathrm{C}$ \\
\hline 3 & Botol air kemasan & 500 am & 20 menit 21 detik & $400{ }^{\circ} \mathrm{C}$ \\
\hline
\end{tabular}


Tabel 3. Rata rata temperture pada presentasi kertas dan kayu

\begin{tabular}{|l|l|l|l|l|l|}
\hline No & \multicolumn{1}{|c|}{$\begin{array}{c}\text { Jenis Bahan } \\
\text { Baku }\end{array}$} & $\begin{array}{c}\text { Massa } \\
\text { jenis } \\
\mathrm{kg} / \mathrm{m}^{3}\end{array}$ & $\begin{array}{c}\text { Laju penguapan air } \\
(\mathrm{kg} / \mathrm{s})\end{array}$ & $\begin{array}{c}\text { Temperatur } \\
\text { nyala api }\end{array}$ & $\begin{array}{c}\text { Efisiensi } \\
(\%)\end{array}$ \\
\hline 1 & $25 \%$ kertas-75\% kayu & 1140,33 & 0,0000444 & $400{ }^{\circ} \mathrm{C}$ & $24,38 \%$ \\
\hline 2 & $50 \%$ kertas-50\% kayu & 1095 & 0,0000464 & $350{ }^{\circ} \mathrm{C}$ & $24,44 \%$ \\
\hline 3 & $75 \%$ kertas-25\% kayu & 1104,67 & 0,0000521 & $300{ }^{\circ} \mathrm{C}$ & $26,77 \%$ \\
\hline
\end{tabular}

\section{METODE PENELITIAN}

Pada penelitian ini terdapat beberapa metode riset yang digunakan, yaitu :

1. Studi Literatur

Studi literatur dilakukan untuk memberikan dasar teori untuk selanjutnya dikembangkan dan diaplikasikan dalam riset ini. Studi literatur terkait dengan perkembangan penggunaan sampah terutama untuk pembangkitan energi listrik.

2. Sampah yang digunakan untuk bahan bakar adalah sampah kering berupa kertas, plastik, dan kayu

3. Perencanaan Boiler

Perencanaan boiler bahan bakar sampah ini menggunakan data komisioning PLTU Mini STT-PLN. Yaitu :

- $\mathrm{P}_{\text {out Boiler }}: 42 \mathrm{psi}=2,9 \mathrm{bar}$

$(1 \mathrm{bar}=14.5 \mathrm{psi})$

- Laju aliran uap : 0,006 kg/s = 21 $\mathrm{kg} / \mathrm{jam}$.

Selanjutnya dilakukan simulasi heat balance dengan menggunakan software cycle tempo. Tahap selanjutnya yaitu penentuan kebutuhan panas dan bahan bakar sehingga diperoleh desain dan ukuran dari Boiler yang terdiri dari ukuran badan, evaporator.

4. Perancangan Boiler

Dari hasil perencanaan boiler tersebut, selanjutnya dilakukan validasi dengan mensimulasinya dengan menggunakan software HTRI. Hasil yang telah divalidasi dengan HTRI selanjutnya dibuat dalam gambar kerja menggunakan software AutoCad.

Sampah pada tempat pembuangan sampah di STT-PLN dipisahkan dan dikeringkan sehingga dapat menjadi bahan bakar boiler tersebut seperti yang ditunjukan oleh gambar 1 dibawah ini :

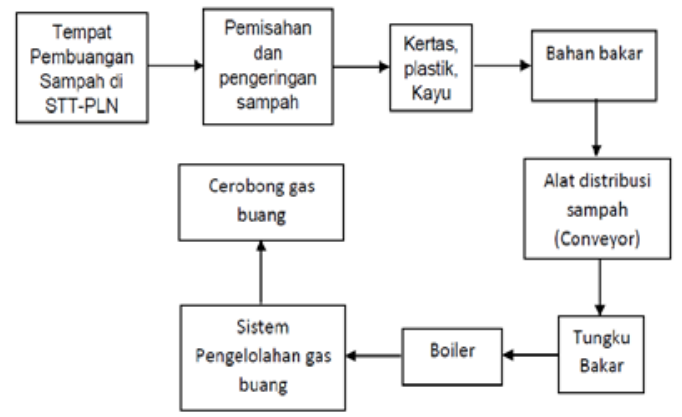

Gambar 1 Digram alir sampah kering sebagai bahan bakar boiler

Sedangkan, pendistribusian bahan bakar sampah sampai ke ruang bakar boiler (furnace) dan pengelolahan gas hasil pembakaran seperti ditunjukan pada gambar 2 dibawah ini :

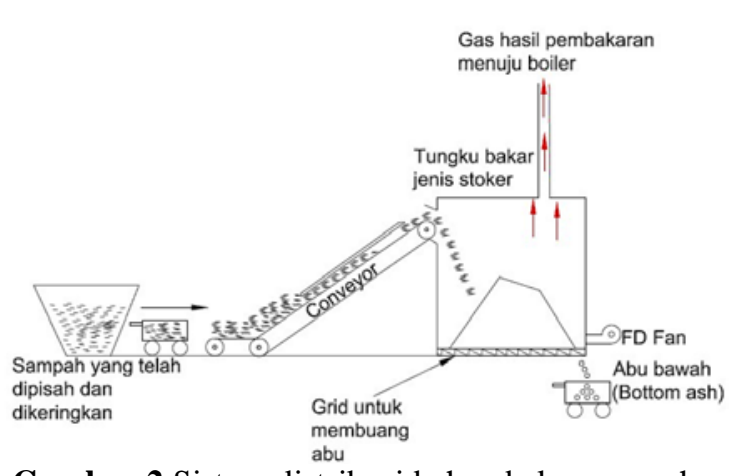

Gambar 2 Sistem distribusi bahan bakar sampah kering sampai ke ruang bakar

\section{HASIL DAN PEMBAHASAN}

Perancangan awal boiler ini digunakan untuk mensimulasikan heat balance dengan menggunakan software cycle tempo. Gambar 3 berikut ini adalah data awal yang digunakan dalam perancangan ini. 


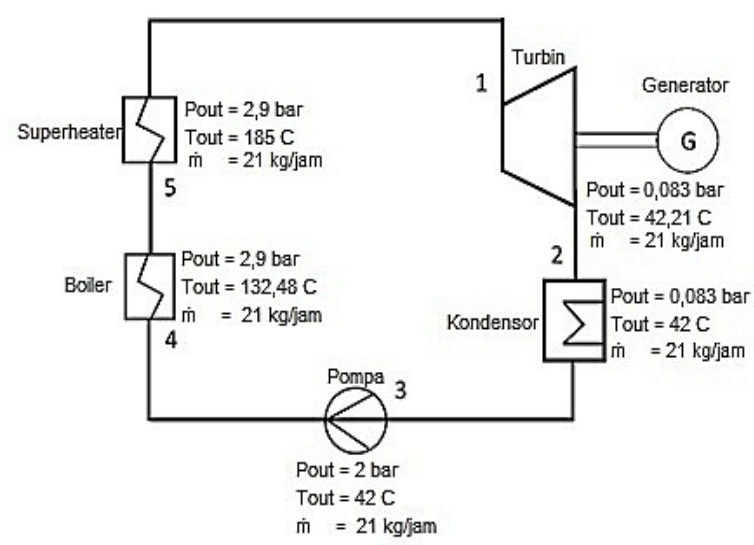

Gambar 3 Kondisi kerja PLTU Mini 3 kW STT-PLN

Simulasi heat balance dilakukan dengan menggunakan perangkat lunak cycle tempo, dengan data yang digunakan seperti ditunjukan pada table 4berikut ini.

Tabel 4 Data awal Simulasi Heat Balance

\begin{tabular}{|l|c|c|}
\hline Parameter & Nilai & Satuan \\
\hline $\mathrm{T}_{\text {out boiler }}$ & 185 & ${ }^{\circ} \mathrm{C}$ \\
\hline $\mathrm{P}_{\text {out boiler }}$ & 2,9 & Bar \\
\hline $\mathrm{T}_{\text {out turbin }}$ & 42,21 & ${ }^{\circ} \mathrm{C}$ \\
\hline $\mathrm{P}_{\text {in kondensor }}$ & 0,083 & $\mathrm{Bar}$ \\
\hline $\mathrm{T}_{\text {out kondensor }}$ & 42 & ${ }^{\circ} \mathrm{C}$ \\
\hline $\mathrm{P}_{\text {out pompa }}$ & 2 & $\mathrm{Bar}$ \\
\hline $\mathrm{T}_{\text {in cooling tower }}$ & 39 & ${ }^{\circ} \mathrm{C}$ \\
\hline $\mathrm{P}_{\text {out cooling tower }}$ & 2 & $\mathrm{Bar}$ \\
\hline $\mathrm{P}_{\text {in cooling tower }}$ & 1 & $\mathrm{Bar}$ \\
\hline $\mathrm{T}_{\text {out cooling tower }}$ & 30 & ${ }^{\circ} \mathrm{C}$ \\
\hline $\mathrm{LHV}$ & 17203,6 & $\mathrm{~kJ} / \mathrm{kg}$ \\
\hline
\end{tabular}

Gambar 4 menunjukan hasil simulasi dari heat balance berdasarkan data table 4 .

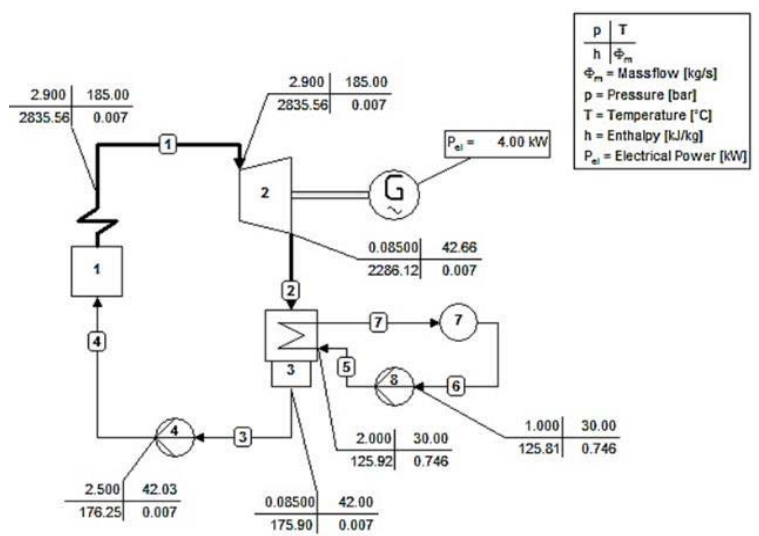

Gambar 4 Simulasi Heat Balance PLTU Mini 3 kW STT-PLN
Data hasil simulasi seperti pada gambar 4 diatas, maka digunakan untuk perencanaan dari boiler untuk PLTU Mini 3kW STT-PLN. Berdasarkan hasil perhitungan, maka diperoleh kebutuhan kalor di boiler dan kebutuhan bahan bakar seperti ditunjukan oleh tabel 5 dibawah ini.

Tabel 5 Hasil Perhitungan kebutuhan kalor dan bahan bakar di Boiler

\begin{tabular}{|l|c|c|}
\hline Parameter & Nilai & Satuan \\
\hline Qeconomiser & 1666,14 & $\mathrm{~kJ} / \mathrm{hr}$ \\
\hline Qevaporator & 50080 & $\mathrm{~kJ} / \mathrm{hr}$ \\
\hline Qtotal & 51746,14 & $\mathrm{~kJ} / \mathrm{hr}$ \\
\hline $\begin{array}{l}\text { Kebutuhan Bahan } \\
\text { Bakar }\end{array}$ & 4,4 & $\begin{array}{l}\mathrm{kg} \mathrm{bahan} \\
\text { bakar } / \mathrm{hr}\end{array}$ \\
\hline
\end{tabular}

Berdasarkan tabel 5 diatas, besarnya kalor yang dibutuhkan di boiler untuk proses pemanasan air sebesar 51746,14 kJ/hr untuk dapat menghasilkan uap sebesar $21 \mathrm{~kg} / \mathrm{hr}$ dengan menggunakan bahan bakar berupa sampah kering berupa kertas, plastic dan kayu. Sedangkan besarnya kebutuhan bahan bakar dengan mengasumsikan efisiensi boiler $70 \%$ yaitu sebesar 4,4 kg bahan bakar tiap jam.

Berdasarkan data-data hasil simulasi dan perhitungan kebutuhan kalor diatas, maka berikut ini adalah desain dan ukuran dari boiler. Yang terdiri dari badan boiler dan evaporator.

\section{Desain dan Ukuran Badan Boiler}

Desain boiler yang telah didapatkan merupakan hasil dari pengumpulan data dari literature dan survei lapangan. Oleh karena itu asumsi spesifikasi perancangan bangun boiler didapatkan data sebagai berikut :

Tabel 6 Data Perancangan Badan Boiler

\begin{tabular}{|l|l|l|}
\hline Parameter & \multicolumn{1}{|c|}{ Nilai } & Satuan \\
\hline Tipe Boiler & $\begin{array}{l}\text { Vertical water tube } \\
\text { boiler }\end{array}$ \\
\hline $\begin{array}{l}\text { Diameter dalam } \\
\text { boiler }\end{array}$ & 800 & $\mathrm{~mm}$ \\
\hline Temperatur operasi & 400 & ${ }^{\circ} \mathrm{C}$ \\
\hline Tekanan operasi & 3 & Bar \\
\hline Bahan bakar & $\begin{array}{l}\text { Sampah kering } \\
\text { (kertas, plastic dan } \\
\text { kayu) }\end{array}$ \\
\hline
\end{tabular}


Berdasarkan tabel 6 diatas, Boiler yang direncanakan tergolong ke dalam steam boiler kapasitas kecil, yaitu kurang dari 10 ton/hr dan bertekanan rendah karena kurang dari 10 atm, sehingga standar perancangan yang digunakan yaitu ASME Section IV. Material dalam merencanakan badan boiler ini menggunakan bahan SA 285 Grade C merupakan material carbon steel untuk boiler pada ASME Section IV. Material SA 285 Grade C. Pada ASME Section IV variabel tinggi tidak digunakan untuk mencari tebal badan boiler, maka disini peneliti menentukan sendiri tinggi badan boiler yaitu $1700 \mathrm{~mm}$. Ketebalan minimal plat yang diijinkan $\mathrm{t}=0,09$ in $=2,5 \mathrm{~mm}$. Jadi dengan Maximum Allowable Working Pressure (MAWP) 43,5 lb/in ${ }^{2}$ ketebalan plat yang direncanakan sebesar 2,5 mm, dan didapatkan diameter luar badan boiler sebesar $805 \mathrm{~mm}$. gambar 5 berikut ini adalah hasil desain dari badan boiler.

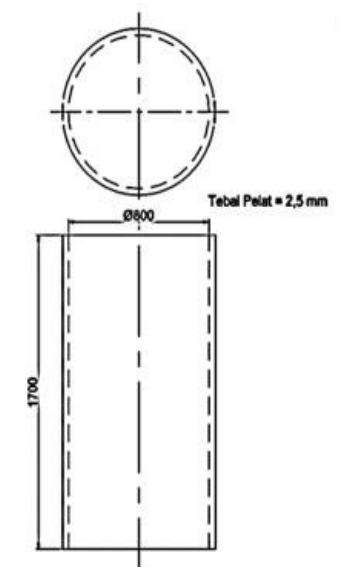

Gambar 5 2D ukuran badan boiler menggunakan perangkat lunak autocad

\section{Desain dan Ukuran Evaporator}

Pipa evaporator yang dipakai pada perancangan boiler ini berukuran 3/4" $(0,0214 \mathrm{~m})$ schedule 40 , dengan pertimbangan untuk mempermudah perawatan, karena seperti ketel komersil. Memiliki diameter dalam 21,4 $\mathrm{mm}$, diameter luar 27,2 $\mathrm{mm}$ dan tebal 2,9 mm dan konduktivitas $\mathrm{kp}=43,3 \mathrm{~W} / \mathrm{mK}$. Material untuk pipa schedule 40 adalah carbon steel pipe (welded/seamless).

Untuk menentukan temperature pada pembakaran sampah kering, maka digunakan referensi yang membahas tentang waktu yang dibutuhkan untuk membakar bahan baku plastik dan besarnya temperatur nyala api api yang dibutuhkan. Tabel 2 dan 3 menunjukan waktu yang dibutuhkan untuk membakar bahan baku besarnya temperatur nyala api. Karena bahan bakar sampah kering yang digunakan dalam boiler berbahan bakar sampah kali ini salah satunya adalah kertas, kayu dan plastik dan presentasi sampai tersebut semua dibagi rata maka hasil temperatur pembekaran ketiga sampah tersebut dengan melihat data diatas adalah Kantong kresek $=350{ }^{\circ} \mathrm{C}$, Botol oli $=365$ ${ }^{\circ} \mathrm{C}$, Botol Air kemasan $=400{ }^{\circ} \mathrm{C}, 50 \%$ kertas $50 \%$ kayu $=350{ }^{\circ} \mathrm{C}$. Jadi, rata rata dari data diatas adalah $367^{\circ} \mathrm{C}$.

Dengan bentuk boiler yang tidak terlalu besar maka diasumsikan temperatur keluar boiler adalah $200{ }^{\circ} \mathrm{C}$ seperti gambar 6 dibawah ini:

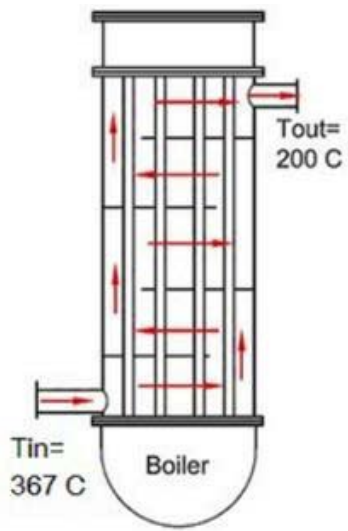

Gambar 6 Aliran gas panas pada boiler

Asumsi properti gas asap = properti udara, dimana :

$$
\begin{aligned}
\mathrm{Ts} & =(367+200) / 2=283,5^{\circ} \mathrm{C} \\
\rho & =1,43 \mathrm{~kg} / \mathrm{m}^{3} \\
\mu & =0,35 \times 10-4 \mathrm{~kg} / \mathrm{m} . \mathrm{s} \mathrm{v} \\
\mu / \rho & =1,39 \times 10-5 \mathrm{~m}^{2} / \mathrm{det} \mathrm{k} \\
& =0,025 \mathrm{~W} / \mathrm{m}^{\circ} \mathrm{C} \mathrm{Cp}=1070 \mathrm{~J} / \mathrm{kg}^{\circ} \mathrm{C} \\
\operatorname{Pr} & =\mu . \mathrm{Cp} / \mathrm{k}=0,8756
\end{aligned}
$$

Kecepatan aliran gas asap yang mengalir dari pipa gas hasil pembakaran untuk memanasi pipa pipa evaporator. Asumsi Diameter dalam pipa gas panas $=4$ in $=102 \mathrm{~mm}, \mathrm{~V}=1,55 \frac{\mathrm{m}}{\mathrm{s}}$

Bilangan Reynolds aliran tersebut 11374 . maka Dalam perhitungan ini aliran gas asap yang memanasi seluruh komponen boiler berupa aliran turbulen berada pada pada bilangan lebih dari 4000.

Berdasarkan analisis perhitungan diperoleh $\mathrm{Nu}=37,98$ Sehingga koefisien konveksi gas asap yang mengalir dari tungku pembakaran melewati komponen boiler (pipa pipa evaporator) diperoleh ho $=9,31 \mathrm{~W} / \mathrm{m}^{2} \mathrm{~K}$. selanjutnya Koefisien Perpindahan Kalor Konveksi hi (koefisien perpindahan panas 
didalam pipa) pada evaporator dapat ditentukan, dimana Air mengalami proses pendidihan.

Beda T, DTe $=$ Ts-Tsat $=151,02{ }^{\circ} \mathrm{C}$.

Untuk perhitungan $\mathrm{h}_{\text {konv }}$ konstanta $\mathrm{C}$ menggunakan 0,62 karena pipa. (0,62 = silinder dan $0,66=$ bola), diperoleh $h_{\text {konv }}=303,78$ $\mathrm{W} / \mathrm{m}^{2} \mathrm{~K}$

Koefisien radiasi dari permukaan pipa dengan suhu Ts ke air pada suhu Ts adalah $\mathrm{h}_{\text {rad }}$ $=7,92 \mathrm{~W} / \mathrm{m}^{2} \mathrm{~K}$. sehingga Koefisien konveksi total adalah $h_{i}=309,72 \mathrm{~W} / \mathrm{m}^{2} \mathrm{~K}$. Koefisien perpindahan panas total pada evaporator $\mathrm{U}_{\mathrm{i}}=$ $41,01 \mathrm{~kJ} / \mathrm{m}^{2} \mathrm{hr} \mathrm{K}$.

Jumlah Pipa Evaporator dapat ditentukan, dimana besarnya Qevaporator dari hasil analisis adalah $50080 \mathrm{~kJ} / \mathrm{hr}$ dan $\mathrm{U}=41,01 \mathrm{~kJ} / \mathrm{m} 2 \mathrm{hr} \mathrm{K}$ dan LMTD 134,67 segingga area perpindahan panas effective di evaporator diperoleh sebesar $=8,83 \mathrm{~m}^{2}$ atau $8830000 \mathrm{~mm}^{2}$. Untuk menentukan jumpah pipa evaporator adalah dengan luas area $8830000 \mathrm{~mm}^{2}$, maka jumlah pipa evaporator diperoleh sebanyak $n=87,6 \sim$ 88 рipa.

Dari data diatas, maka dibuat simulasi dalam HTRI, adapun hasil simuasi HTRI adalah sebagai berikut :

Tabel 7 Hasil Simulasi desain Evaporator dengan perangkat lunak HTRI

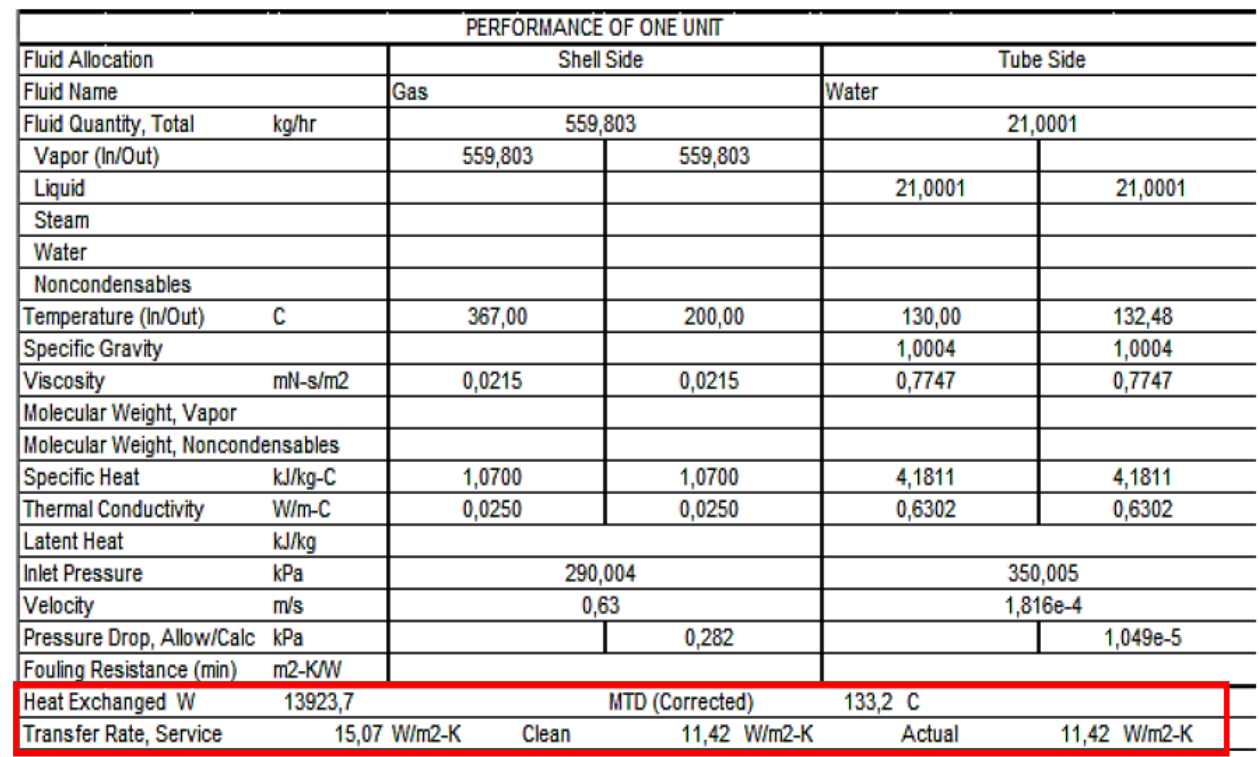

Sedangkan untuk memverifikasi hasil perhitungan manual jumlah pipa, maka digunakan perangkat lunak HTRI. Adapun hasil dari simulasi tersebut dapat dilihat pada gambar 7 dibawah ini.
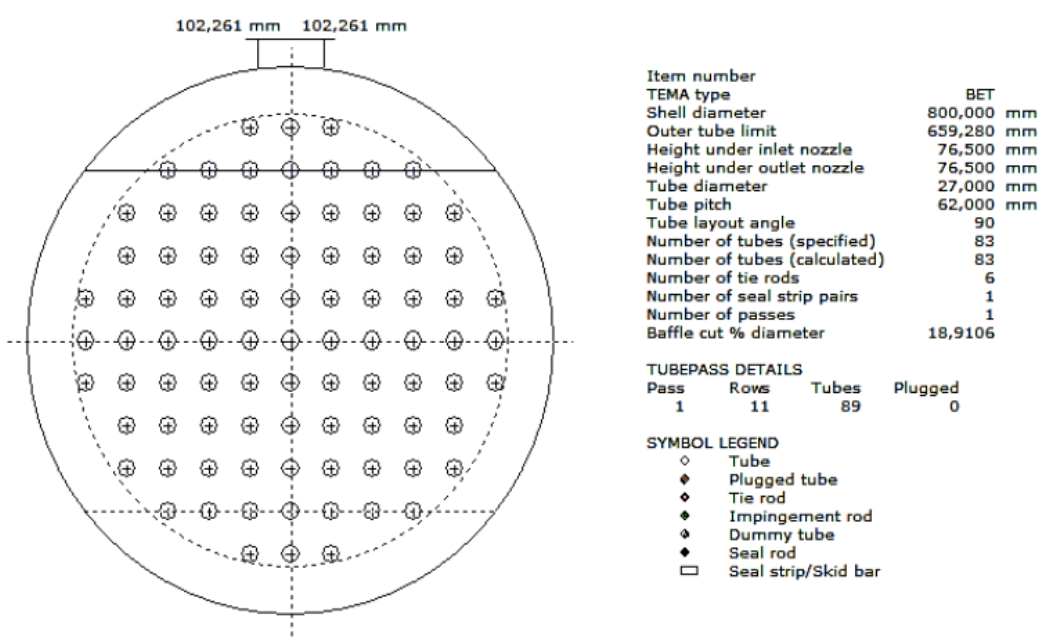

Gambar 7 Hasil Desain 2D Evaporator pada program HTRI 


\section{Desain dan Ukuran Economiser}

Panas yang dibutuhkan ekonomiser = $1666,14 \mathrm{~kJ} / \mathrm{hr}$. Ukuran diameter pipa untuk ekonomiser disamakan dengan ukuran pipa pada evaporator, yaitu Do $=27,2 \mathrm{~mm}$ dan $\mathrm{Di}=21,4$ $\mathrm{mm}$. Karena gas panas yang dipakai pada ekonomiser adalah gas panas sisa dari evaporator maka temperatur awal masuk ekonomiser adalah $200{ }^{\circ} \mathrm{C}$ dan temperature keluar ekonomiser adalah 100 oC seperti yang ditunjukan pada gambar 8 .

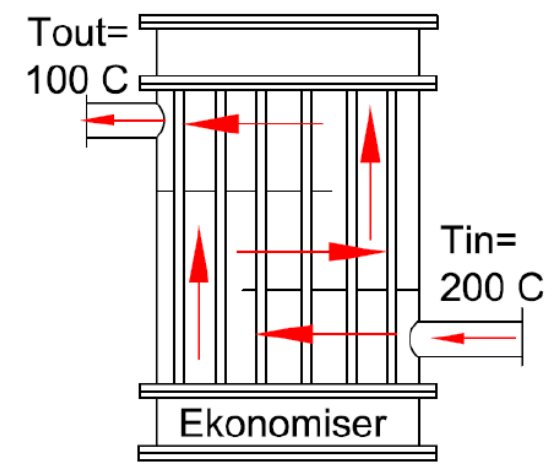

Gambar 8 Aliran Gas panas pada economizer koefisien perpindahan panas sisi luar pipa) pada ekonomiser sama dengan koefisien perpindahan panas sisi luar pipa pada evaporator yaitu ho $=$ 9,31 W/m $/ \mathrm{m}^{2} \mathrm{~K}$. sedangkan dari perhitungan diperoleh koefisien Perpindahan Kalor Konveksi hi (koefisien perpindahan panas didalam pipa) pada ekonomiser yaitu : hkonv $=182,27 \mathrm{~W} / \mathrm{m}^{2} \mathrm{~K}$ dan hrad $=3,376 \mathrm{~W} / \mathrm{m}^{2} \mathrm{~K}$. sehingga $\mathrm{h}$ total hi $=$ 184,802 W/m2K. Koefisien perpindahan panas total dalam ketel adalah $\mathrm{Ui}=43,2 \mathrm{~kJ} / \mathrm{m}^{2} \mathrm{hr} \mathrm{K.} \Delta$ LMTD = 85 Jadi, luas bidang yang dipanaskan sebesar $0,46 \mathrm{~m}^{2}=460000 \mathrm{~mm}^{2}$, sehingga jumlah pipa 17,11 $\sim 18$ pipa. Sehingga minimal pipa pada ekonomiser adalah 18 pipa dengan panjang $400 \mathrm{~mm}$.

Dari hasil perhitungan diatas, maka dibuat simulasi dalam perangkat lunak HTRI seperti yang ditunjukan pada tabel 8 dibawah ini.

Tabel 8 Hasil Simulasi Perhitungan Economiser dengan perangkat lunak HTRI

\begin{tabular}{|c|c|c|c|c|c|}
\hline \multicolumn{6}{|c|}{ PERFORMANCE OF ONE UNT } \\
\hline \multicolumn{2}{|l|}{ Fluid Allocation } & \multicolumn{2}{|c|}{ Shell Side } & \multicolumn{2}{|c|}{ Tube Side } \\
\hline \multicolumn{2}{|l|}{ Fluid Name } & \multicolumn{2}{|l|}{ Gas } & \multicolumn{2}{|l|}{ Water } \\
\hline Fluid Quantity, Total & $\mathrm{kg} / \mathrm{hr}$ & \multicolumn{2}{|c|}{23,1001} & \multicolumn{2}{|c|}{21,0001} \\
\hline \multicolumn{2}{|l|}{ Vapor (In/Out) } & 23,1001 & 23,1001 & & \\
\hline \multicolumn{2}{|l|}{ Liquid } & & & 21,0001 & 21,0001 \\
\hline \multicolumn{6}{|l|}{ Steam } \\
\hline \multicolumn{6}{|l|}{ Water } \\
\hline \multicolumn{6}{|l|}{ Noncondensables } \\
\hline Temperature (In/Out) & $\mathrm{C}$ & 200,00 & 100,00 & 48,00 & 58,00 \\
\hline \multicolumn{2}{|l|}{ Specific Gravity } & & & 1,0004 & 1,0004 \\
\hline Viscosity & $\mathrm{mN}-\mathrm{s} / \mathrm{m} 2$ & $1,40 \mathrm{e}-4$ & $1,40 \mathrm{e}-4$ & 0,7747 & 0,7747 \\
\hline \multicolumn{6}{|l|}{ Molecular Weight, Vapor } \\
\hline \multicolumn{6}{|c|}{ Molecular Weight, Noncondensables } \\
\hline Specific Heat & $\mathrm{kJ} / \mathrm{kg}-\mathrm{C}$ & 1,0700 & 1,0700 & 4,1811 & 4,1811 \\
\hline Thermal Conductivity & $W / m-C$ & 0,0250 & 0,0250 & 0,6302 & 0,6302 \\
\hline Latent Heat & $\mathrm{kJ} / \mathrm{kg}$ & & & & \\
\hline Inlet Pressure & $\mathrm{kPa}$ & \multirow{2}{*}{\multicolumn{2}{|c|}{$\begin{array}{l}290,004 \\
3.688 \mathrm{e}-2\end{array}$}} & \multicolumn{2}{|c|}{350,005} \\
\hline Velocity & $\mathrm{m} / \mathrm{s}$ & & & \multicolumn{2}{|c|}{$2,361 \mathrm{e}-3$} \\
\hline Pressure Drop, Allow/Calc & $\mathrm{kPa}$ & & 0,095 & & $1,547 \mathrm{e}-4$ \\
\hline Fouling Resistance (min) & $\mathrm{m} 2-\mathrm{K} W \mathrm{~W}$ & & & & \\
\hline Heat Exchanged W & \multicolumn{2}{|l|}{465,247} & MTD (Corrected) & \multicolumn{2}{|l|}{$89,6 \mathrm{C}$} \\
\hline Transfer Rate, Service & 27, & W/m2-K & 11,83 W/m2-K & Actual & $11,83 \mathrm{~W} / \mathrm{m} 2-\mathrm{K}$ \\
\hline
\end{tabular}

Sedangkan untuk memverifikasi data hasil perhitungan manual, maka berikut ini hasil simulasi jumlah pipa economizer ditunjukan oleh gambar 9 dibawah ini : 

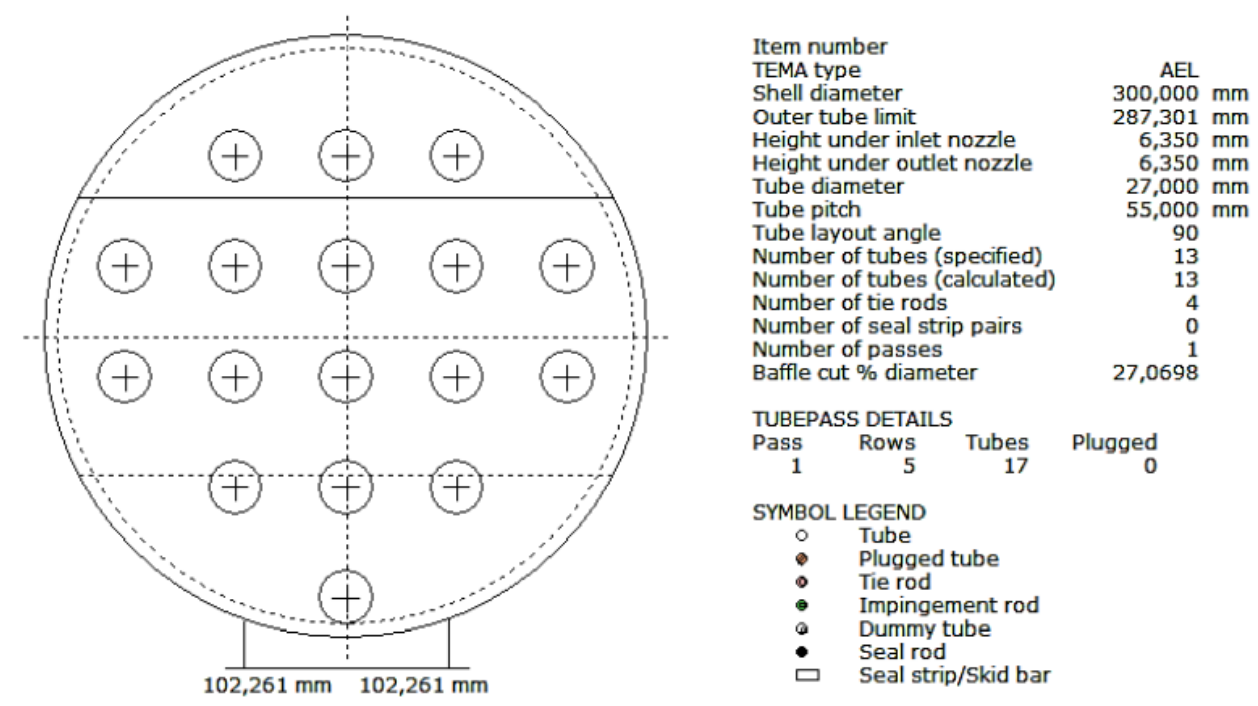

Gambar 9 hasil simulasi jumlah pipa economizer menggunakan perangkat lunak HTRI

\section{KESIMPULAN}

Berdasarkan hasil analisis, dapat ditarik kesimpulan :

1. Untuk Tekanan boiler 2.9 bar dan laju aliran steam $21 \mathrm{~kg} / \mathrm{hr}$, besarnya kalor yang dibutuhkan di boiler sebesar 51746,14 kJ/hr dengan menggunakan sampah kering dengan laju aliran 4,4 kg bahan bakar/hr

2. Luas bidang yang dipanaskan untuk evaporator dan economiser pada perancangan boiler berdasarkan verifikasi menggunakan perangkat lunak HTRI masing-masing $8,95 \mathrm{~m}^{2}$ dan $0,45 \mathrm{~m}^{2}$

3. Jumlah pipa evaporator dan economiser masing-masing berjumlah 88 dan 18 pipa.

\section{DAFTAR PUSTAKA}

Djokosetyardjo, M.J., Ketel Uap, PT Pradnya Paramita, Jakarta, 1987

Djokosetyardjo, M.J., Pembahasan Lebih Lanjut Tentang Ketel Uap, PT Pradnya Paramita, Jakarta, 1987

Kakac,Sadik, Boiler,Evaporator and Condensor, John Wiley \& sons, 1991

Holman, J.P., Perpindahan Kalor, Jakarta Erlangga, 1994

Ardiyanto, Dwi., 2013. Rancang Bangun Boiler Untuk Proses Pemanasan Sistem Uap Pada Industri Tahu Dengan Menggunakan Catia V5. Semarang : Universitas Negeri Semarang
Helmi, Irsan., 2007.Perancangan Boiler Untuk PLTU Berkapasitas 7 MW. Jakarta : Universitas Indonesia

Dong, Trang T.T. \& Lee, Byeong-Kyu , 2009. Analysis of potential RDF resources from solid waste and their energy values in the largest industrial city of Korea. Waste Management, 29, 1725-1731

Ade Fatimah, 2009. Analisis Kelayakan Usaha Pengolahan Sampah Menjadi Pembangkit Listrik Tenaga Sampah(Pltsa) Di Kota Bogor Bogor : Institut Pertanian Bogor

Bizzy I, Setiadi R, Studi perhitungan alat penukar kalor tipe shell and tube dengan program heat transfer research inc (HTRI). Jurnal Rekayasa Mesin. Volume 13(1), hal. 67-77. 2013

Kadir, Kajian pemanfaatan sampah plastik sebagai sumber bahan bakar cair. Jurnal Ilmiah Teknik Mesin. Volume 3 (2), hal. 223-228. 2012

Adrian Nusalim, 2012. Perancangan ketel uap untuk PT. Hongxing Algae International. Surabaya : Universitas Kristen Petra

Agung Sudrajad, Uji Ultimat Dan Proksimat Sampah Kota Untuk Sumber Energi Alternatif Pembangkit Tenaga. 2014 .Seminar Nasional Teknik Mesin Universitas Trisakti. hal. KE13 1 -6.

Caysa, Ardi., 2012.Analisa Potensi Refuse Derived Fuel(RDF) Dari sampah Unit Pengelolaan Sampah (UPS) Di Kota Depok(Studi Kasus UPS Grogol,UPS Permata Regency,UPSCilangkap.Jakarta : Universitas Indonesia 
Edy, Jasmid. 2016. Tungku Sidaus Pemusnah Sampah Cepat dan Tepat. Jurnal Power Plant, Vol. 4, No. 3, ISSN : 2356-1513

Novita, Marya Dian. Perhitungan Nilai Kalor Berdasarkan Komposisi dan Karakteristik Sampah Perkotaan Indonesia Dalam Konsep Waste To Energy. 2010.Jurnal Teknik Lingkungan Volume 16 Nomor 2, (hal. 103-114) 